\title{
Polymorphisms of the mannose binding lectin $(M B L 2)$ gene are related to protein plasma levels but not with visceral leishmaniasis in a northeastern brazilian population
}

\author{
E.L. Silva ${ }^{1}$, A.L. Pestana ${ }^{2}$, S.G. Monteiro ${ }^{3}$, A.J.M. Caldas ${ }^{1}$, \\ F.J.B. Patrício ${ }^{4}$, M.D.C. Santos ${ }^{5}$, M.J. Campos $^{6}$ and M.M.G. Pimentel ${ }^{7}$ \\ ${ }^{1}$ Departamento de Enfermagem da Universidade Federal do Maranhão, São \\ Luís, MA, Brasil \\ ${ }^{2}$ Universidade Federal de Santa Catarina, Florianópolis, SC, Brasil \\ ${ }^{3}$ Departamento de Biologia da Universidade Federal do Maranhão, São \\ Luís, MA, Brasil \\ ${ }^{4}$ Laboratório de Estudos Genômicos e de Histocompatibilidade, Hospital \\ Universitário da Universidade Federal do Maranhão, São Luis, MA, Brasil \\ ${ }^{5}$ Centro de Pesquisa Clínica do Hospital Universitário, São Luís, MA, Brasil \\ ${ }^{6}$ Laboratório de genética humana do Instituto Osvaldo Cruz /Fundação \\ Osvaldo Cruz, Rio de Janeiro, RJ, Brasil \\ ${ }^{7}$ Universidade do Estado do Rio de Janeiro, Laboratório de genética \\ humana/Departamento de genética, Instituto de biologia Roberto Alcântara \\ Rio de Janeiro, RJ, Brasil
}

Corresponding author: F.J.B. Patrício

E-mail: fernando.patricio@huufma.br

Genet. Mol. Res. 18 (2): gmr18148

Received September 18, 2018

Accepted May 24, 2019

Published June 18, 2019

DOI http://dx.doi.org/10.4238/gmr18148

\begin{abstract}
Mannose-binding lectin (MBL) is a lectin complement protein encoded by the $M B L 2$ gene that has an important role in the control of infections caused by intracellular pathogens. However, there is no consensus about the effect of MBL2 polymorphism and MBL levels in leishmaniasis infections. We investigated the implications of $M B L 2$ gene variants as well as MBL serum levels and occurrence of visceral leishmaniosis (VL) caused by Leishmania chagasi. A case-control analytic study was performed on 161 patients with VL and 161 healthy individuals in a northeast region of Brazil. The alleles of exon 1 $(M B L 2 * \mathrm{~A}, M B L 2 * \mathrm{~B}, M B L 2 * \mathrm{C}$ and $M B L 2 * \mathrm{D})$ and promoter region (-
\end{abstract}


$550 \mathrm{~L} / \mathrm{H},-221 \mathrm{Y} / \mathrm{X}$ and $+4 \mathrm{P} / \mathrm{Q}$ ) were identified by automatic sequencing and the MBL serum levels were determined using an ELISA kit. MBL serum levels were similar in VL patients compared to the healthy controls. Also, allelic, genotype and haplotype frequencies of variants in exon 1 and promoter region did not significantly differ between case and control groups. Overall, our data show that MBL2 polymorphisms within the structural gene as well as the promoter region influence functional MBL serum levels but are not associated with susceptibility to $L$. chagasi infection in this population. We observed a lack of consensus regarding the association of MBL 2 polymorphisms with leishmaniasis worldwide, indicating that the influence of genetic variations can differ in different populations and with differences in parasite/vector relationship.

Key words: Immunogenetics; Innate immune system; Mannose binding lectin; Leishmania chagasi

\section{INTRODUCTION}

Visceral leishmaniasis (VL) is a chronic, severe disease that can be fatal if untreated. In Brazil, it is caused by the intracellular pathogen Leishmania chagasi. The disease is characterized by a broad clinical spectrum, which may vary from asymptomatic, discrete clinical manifestations (oligosymptomatic) and moderate to severe (Kevric et al., 2002; Laison \& Rangel, 2005). Several factors may influence the evolution of the disease, including co-infection with human immunodeficiency syndrome (HIV), nutritional status, age (Badaro et al., 1986; Queiroz et al., 2004) and variations in genes that regulate the immune response (Sakthianandeswaren et al., 2009).

Mannose-binding lectin (MBL) is a soluble protein that is part of the innate immune system, and plays an important role in recognition and elimination of pathogens through phagocytosis promotion and complement cascade activation. By binding to its target, MBL triggers lectin pathway, leading to the production of $\mathrm{C} 3 \mathrm{~b}$ opsonizing fragments favoring phagocytosis via CR1 receptors of phagocytes. Previous studies have shown that MBL binds to a wide variety of microorganisms, including Leishmanias sp. (Fraser et al., 1998; Worthley et al., 2005).

In humans, MBL protein in the serum is a product of MBL2 gene, located on chromosome 10 (q21-24), formed by four exons (Taylor et al., 1989; Sastry et al., 1989). Variants at the promoter region and in exon 1 of the MBL2 gene result in considerable variations in the amount and structure of the MBL protein, respectively (Terai et al., 2003; Larsen et al., 2004).

There are three mutations located in exon 1 that involve an exchange of nucleotide bases in codons $52(\mathrm{C}>\mathrm{T}), 54(\mathrm{G}>\mathrm{A})$ and $57(\mathrm{G}>\mathrm{A})$, which lead to low production of MBL, corresponding to allelic variants $M B L 2 * \mathrm{D}, M B L 2 * \mathrm{~B}$ e $M B L 2 * \mathrm{C}$, respectively. These variations are commonly referred as allele $\mathrm{O}$ since they have a similar physiological effect, which culminates with reduction of circulating MBL level. The wild allele that produces normal protein levels is termed $M B L 2 * \mathrm{~A}$ (Lipscombe et al., 1992; Madsen et al., 1994). Thus, homozygous for the wild type allele (A/A) show higher levels of MBL compared to heterozygous $(\mathrm{A} / \mathrm{O})$, whereas mutant homozygotes $(\mathrm{O} / \mathrm{O})$ produce amounts of $\mathrm{MBL}$ almost undetectable by ELISA. Polymorphic sites of promoter region are at positions -550 [C>G], -221 $[\mathrm{G}>\mathrm{C}]$ and $+4[\mathrm{C}>\mathrm{T}]$ representing loci $\mathrm{H} / \mathrm{L}, \mathrm{X} / \mathrm{Y}$, and $\mathrm{P} / \mathrm{Q}$, respectively (Garred et al., 2006). 
Some studies have evaluated the influence of polymorphisms and MBL serum levels regarding leishmaniasis susceptibility. Recently, we have demonstrated that MBL levels are not associated with the development of VL (Silva et al., 2015). However, MBL level assay is a phenotypic representation that can be influenced by the presence of the infectious agent itself. Thus, the aim of the present study was to investigate the association of $M B L 2$ gene polymorphisms and MBL levels in the occurrence of VL caused by L. chagasi.

\section{MATERIAL AND METHODS}

\section{Study design}

We investigated 161 unrelated patients with VL from a northeast region of Brazil (50.3\% males and 49.7\% females; age range: 1 - 51 years; $5.1 \pm 7.6$ mean age) and 161 unrelated healthy individuals, with no history of Leishmania $s p$ infection, from the same area (19.3\% males and $80.7 \%$ females; age range: 1 - 74 years; $29.1 \pm 13.5$ mean age).

\section{Sample collection and characterization}

The individuals in VL group were those with suggestive VL syndrome (fever more than two weeks) accompanied by at least one of the following changes: a) splenomegaly, b) hepatomegaly, c) anemia, (leukopenia or thrombocytopenia) previously diagnosed by the presence of amastigote forms of L. chagasi in bone marrow smear. All patients of the study were followed at the principal hospitals and referral clinics for VL in the city of São Luís, MA, Brazil.

Healthy volunteers from the same endemic area, unrelated to those included in the VL group, were recruited to integrate the control group. The inclusion criteria for the control group were individuals who had no signs and symptoms suggestive of VL, as previously described, and serologically negative for $L$. chagasi.

\section{Ethical approval}

Data collection occurred after the approval of the project by the Committee for Ethic in Research with human beings of the university Hospital of the Federal University of Maranhão (Approval no. 076/2010). A questionnaire containing identification data, epidemiological markers, clinical characteristics and blood tests was used. The collection of biological material for analysis began only after authorization by the individuals (sick or healthy) or their guardian, by signing a free and informed consent form.

\section{MBL serum level measurement}

MBL serum levels of all samples were measured by enzyme-linked immunosorbent assay MBL Oligomer ELISA Kit (Bioporto, Copehagen, DK), according to the manufacturer's instructions. The detection limit of assay was $0.02 \mathrm{ng} / \mathrm{mL}$.

\section{Molecular analysis}

Genomic DNA was isolated using Illustra ${ }^{\mathrm{TM}}$ blood genomic prep mini spin (GE Healthcare, UK) according to the manufacturer's instructions. Molecular analysis of the exon 1 and the promoter region of $M B L 2$ gene was performed by bidirectional sequencing using the Big 
Dye Terminator v3.1 Kit (Applied Biosystems, USA) and oligonucleotides previously described (Madsen et al., 1998).

\section{Statistical Analysis}

Data were analyzed using SPSS for Windows 17.0 (2007). Initially, the Shapiro-Wilk normality test of MBL serum levels was applied and, due to its abnormal distribution, nonparametric Kruskal Wallis and Mann-Whitney test was used. To evaluate MBL concentration between different haplotypes within each group (case and control), the Kruskal Wallis test was used. In the assessment of MBL concentration from each haplotype between groups (case and control), the Mann-Whitney test was used. The odds ratio was calculated with a 95\% confidence interval. Later, in order to verify the association of different haplotypes with different groups (case and control) the chi-square independence test was applied. The significance level for rejecting the null hypothesis was $5 \%$, i.e. a value of $\mathrm{P}<0.05$ was considered as significant.

\section{RESULTS}

\section{$M B L 2$ exon 1 and promoter variants frequencies}

The genotyping of six variants in $M B L 2$ gene was successfully performed in all 322 samples. The frequency of MBL2 exon 1 alleles are shown in Table 1. There was no statistically significant difference in allele and genotypes frequencies between groups (Table 1). The structural genotypes (A/A, A/O and $\mathrm{O} / \mathrm{O}$ ) showed no significant difference between groups (Table 1). The wild homozygous genotype (A/A) showed higher frequency in both groups, while the heterozygous individuals $(\mathrm{A} / \mathrm{O})$ that had a wild allele and one mutant allele $(\mathrm{B}, \mathrm{C}$ or $\mathrm{D})$, represented the second most frequent genotype in both groups. The defective homozygous genotype $(\mathrm{O} / \mathrm{O})$ had the lowest frequency in VL and control healthy individuals (Table 1).

Table 1. Allelic and genotypic frequencies of the MBL2 exon1 polymorphisms in visceral leishmaniasis patients and healthy controls.

\begin{tabular}{|c|c|c|c|c|}
\hline \multirow{2}{*}{$\begin{array}{l}\text { Exon } 1 \\
\text { Variants }\end{array}$} & \multirow{2}{*}{$\begin{array}{l}\text { Cases } \\
n=161(\%)\end{array}$} & \multirow{2}{*}{$\begin{array}{l}\text { Controls } \\
n=161(\%)\end{array}$} & \multicolumn{2}{|l|}{ Cases vs Controls } \\
\hline & & & OR $(95 \%$ CI $)$ & Pvalue $^{\mathrm{a}}$ \\
\hline$M B L 2 * \mathrm{~A}$ & $236(73.2)$ & $246(76.4)$ & 1 & Reference \\
\hline$M B L 2 * \mathrm{~B}$ & $42(13.4)$ & $49(15.2)$ & $0.89[0.57-1.4]$ & 0.62 \\
\hline$M B L 2 * \mathrm{C}$ & $35(10.8)$ & $21(6.5)$ & $1.73[0.98-3.07]$ & 0.05 \\
\hline$M B L 2 * \mathrm{D}$ & $9(2.8)$ & $6(1.8)$ & $1.56[0.54-4.46]$ & 0.39 \\
\hline \multicolumn{5}{|c|}{ GENOTYPES $M B L 2 *$} \\
\hline AA & $88(54.7)$ & $94(58.4)$ & 1 & Reference \\
\hline $\mathrm{AO}$ & $60(37.3)$ & $58(36)$ & $1.11[0.61-3.57]$ & 0.67 \\
\hline $\mathrm{OO}$ & $13(8)$ & $9(5.6)$ & $1.54[0.62-3.78]$ & 0.34 \\
\hline \multicolumn{5}{|c|}{ Recessive Model } \\
\hline AA & $88(54.7)$ & $94(58.4)$ & 1 & Reference \\
\hline $\mathrm{AO}+\mathrm{OO}$ & $73(45.3)$ & 67 (41.6) & $1.16[0.74-1.80]$ & 0.49 \\
\hline \multicolumn{5}{|c|}{ Dominant Model } \\
\hline $\mathrm{AA}+\mathrm{AO}$ & $148(92)$ & $152(94.4)$ & 1 & Reference \\
\hline $\mathrm{OO}$ & $13(8)$ & $9(5.6)$ & $1.48[0.61-3.57]$ & 0.37 \\
\hline
\end{tabular}

OR: odds ratio; ${ }^{\mathrm{a}} \mathrm{P}$ values were calculated by a chi square test 
In the promoter region of $M B L 2$, the most frequent alleles for the case and control groups were: $-550 \mathrm{~L},-221 \mathrm{Y}$ and $+4 \mathrm{P}$ (Table 2). There was no significant difference in allele frequency of these variations between groups. In addition, investigation of their respective genotypes also revealed no statistical difference. As observed for variants in exon 1, the polymorphisms in the promoter region also had no association with VL occurrence in any of evaluated models (Table 2).

Table 2. Allelic and genotypic frequencies of MBL2 promoter polymorphisms in visceral leishmaniasis patients and healthy controls.

\begin{tabular}{|c|c|c|c|c|}
\hline \multirow[t]{2}{*}{ Promoter variant } & \multirow{2}{*}{$\begin{array}{l}\text { Cases } \\
n=161(\%)\end{array}$} & \multirow{2}{*}{$\begin{array}{l}\text { Controls } \\
\mathrm{n}=161(\%)\end{array}$} & \multicolumn{2}{|l|}{ Cases vs Controls } \\
\hline & & & OR $(95 \%$ CI $)$ & P value $^{\mathrm{a}}$ \\
\hline \multicolumn{5}{|c|}{ ALLELES -550 C/G (L/H) } \\
\hline $\mathrm{C}(\mathrm{L})$ & $218(67.7)$ & $216(67)$ & 1 & Reference \\
\hline G (H) & $104(32.3)$ & $106(32.9)$ & $0.97[0.69-1.35]$ & 0.86 \\
\hline \multicolumn{5}{|c|}{ GENOTYPES -550 C/G (L/H) } \\
\hline $\mathrm{CC}(\mathrm{LL})$ & $80(46.7)$ & $70(43.5)$ & 1 & Reference \\
\hline $\mathrm{CG}(\mathrm{LH})$ & $58(36)$ & $76(47.2)$ & $0.66[0.41-1.06]$ & 0.09 \\
\hline GG (HH) & $23(14.3)$ & $15(9.3)$ & $1.34[0.65-2.77]$ & 0.42 \\
\hline \multicolumn{5}{|l|}{ Recessive Model } \\
\hline $\mathrm{CC}$ & $80(46.7)$ & $70(43.5)$ & 1 & Reference \\
\hline $\mathrm{CG}+\mathrm{GG}$ & $81(53.3)$ & $91(56.5)$ & $0.77[0.50-1.20]$ & 0.26 \\
\hline \multicolumn{5}{|l|}{ Dominant Model } \\
\hline $\mathrm{CC}+\mathrm{CG}$ & $138(85.7)$ & $146(90.7)$ & 1 & Reference \\
\hline GG & $23(14.3)$ & $15(9.3)$ & $1.62[0.81-3.23]$ & 0.16 \\
\hline \multicolumn{5}{|c|}{ ALLELES -221 G/C (Y/X) } \\
\hline $\mathrm{G}(\mathrm{Y})$ & $291(90.3)$ & $276(85.7)$ & 1 & Reference \\
\hline $\mathrm{C}(\mathrm{X})$ & $31(9.7)$ & $46(14.3)$ & $0.63[0.39-1.03]$ & 0.06 \\
\hline \multicolumn{5}{|c|}{ GENOTYPES -221 G/C (Y/X) } \\
\hline GG (YY) & $133(82.6)$ & $120(74.5)$ & 1 & Reference \\
\hline GC (YX) & $25(15.5)$ & $36(22.4)$ & $0.62[0.35-1.10]$ & 0.10 \\
\hline $\mathrm{CC}(\mathrm{XX})$ & $3(1.9)$ & $5(3.1)$ & $0.54[0.12-2.31]$ & 0.4 \\
\hline \multicolumn{5}{|l|}{ Recessive Model } \\
\hline GG & $133(82.6)$ & $120(74,5)$ & 1 & Reference \\
\hline $\mathrm{GC}+\mathrm{CC}$ & $28(17.4)$ & $41(25,5)$ & $0.61[0.35-1.05]$ & 0.07 \\
\hline \multicolumn{5}{|l|}{ Dominant Model } \\
\hline $\mathrm{GG}+\mathrm{GC}$ & $158(98.1)$ & $156(96.9)$ & 1 & Reference \\
\hline $\mathrm{CC}$ & $3(1.9)$ & $5(3.1)$ & $0.59[0.13-2.52]$ & 0.69 \\
\hline \multicolumn{5}{|l|}{ +4 C/T (P/Q) } \\
\hline $\mathrm{C}(\mathrm{P})$ & $233(72.3)$ & $236(73.2)$ & 1 & Reference \\
\hline $\mathrm{T}(\mathrm{Q})$ & $89(27.7)$ & $86(26.8)$ & $1.06[0.75-1.50]$ & 0.72 \\
\hline \multicolumn{5}{|c|}{ GENOTYPES +4C/T (P/Q) } \\
\hline CC (PP) & $85(52.8)$ & $91(56.5)$ & 1 & Reference \\
\hline $\mathrm{CT}(\mathrm{PQ})$ & $63(39.1)$ & $55(34.2)$ & $1.22[0.76-1.95]$ & 0.39 \\
\hline TT (QQ) & $13(8.1)$ & $15(9.3)$ & $0.92[0.41-2.06]$ & 0.85 \\
\hline \multicolumn{5}{|l|}{ Recessive model } \\
\hline CC (PP) & $85(52.8)$ & $91(56.5)$ & 1 & Reference \\
\hline $\mathrm{CT}(\mathrm{PQ})+\mathrm{TT}(\mathrm{QQ})$ & $76(47.2)$ & $70(43.5)$ & $1.16[0.74-1.80]$ & 0.50 \\
\hline \multicolumn{5}{|l|}{ Dominant model } \\
\hline $\mathrm{CC}+\mathrm{CT}(\mathrm{PP}+\mathrm{PQ})$ & 148 (91.9) & $146(90.7)$ & 1 & Reference \\
\hline $\mathrm{TT}(\mathrm{QQ})$ & $13(8.1)$ & $15(9.3)$ & $0.85[0.39-1.85]$ & 0.69 \\
\hline
\end{tabular}

OR: odds ratio; ${ }^{a} \mathrm{P}$ values were calculated by a chi square test

\section{Association of MBL levels and MBL2 exon 1 gene variants}

MBL levels in each genotype relative to exon 1 polymorphisms are shown in Figure 1. In both groups, there is a significant difference on the average concentration of MBL 
among the three genotypes $(\mathrm{P}<0.0001)$, that is homozygous individuals for the functional allele (AA) have significantly higher levels than heterozygotes (AO) which, in turn, have higher levels than defective homozygotes (OO).

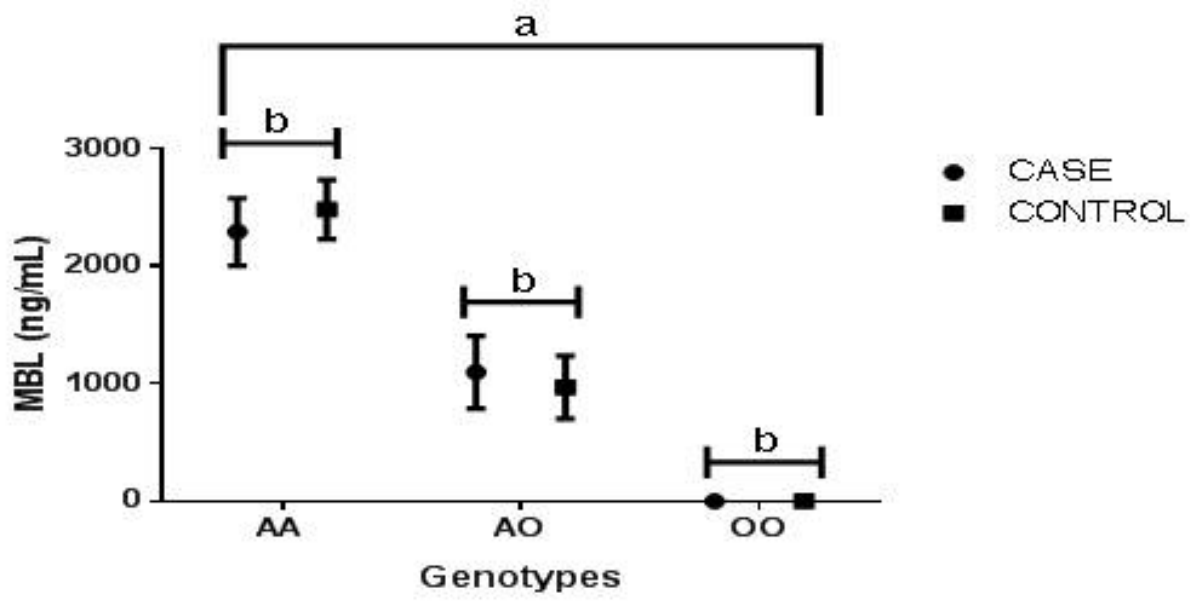

Figure 1. Distribution of MBL serum levels in Visceral Leishmaniasis patients and healthy controls. $\left({ }^{\mathrm{a}}\right)$ Kruskall Wallis test $\mathrm{P}<0,05 ;\left({ }^{b}\right)$ Mann-Whitney test $\mathrm{P}>0,05 . M B L$ : mannose binding lectin

However, no significant difference in mean MBL concentrations of each genotype was observed when comparing the case and control groups (Figure 1). The median value for MBL serum level of AA genotype was $2293.4 \mathrm{ng} / \mathrm{mL}$ vs $2484.4 \mathrm{ng} / \mathrm{mL}(\mathrm{P}=0.68)$ for case and control groups, respectively. The heterozygotes (AO) median levels were 1098.4 vs $970.4(\mathrm{P}=0.65)$ while the $\mathrm{OO}$ genotypes presented null levels of the MBL serum protein in both groups (Figure $1)$.

\section{Association of MBL levels and MBL2 haplotypes}

The distribution of reconstructed haplotypes of MBL2 and their respective MBL levels are shown in Table 3.

Table 3. Distribution of MBL2 haplotypes and MBL levels in visceral leishmaniasis patients and healthy controls.

\begin{tabular}{|c|c|c|c|c|c|c|}
\hline \multirow[t]{2}{*}{ HAPLOTYPE } & \multicolumn{2}{|l|}{ Cases } & \multicolumn{2}{|l|}{ Controls } & \multicolumn{2}{|c|}{ Cases vs Controls } \\
\hline & $n=322(\%)$ & $\begin{array}{l}\text { MBL Level } \\
(\mathrm{ng} / \mathrm{mL})\end{array}$ & $\mathrm{n}=322(\%)$ & $\begin{array}{l}\text { MBL Level } \\
(\mathrm{ng} / \mathrm{mL})\end{array}$ & $P$ value $\mathrm{MBL}^{\mathrm{a}}$ & $\begin{array}{l}\text { P value } \\
\text { frequency }^{b}\end{array}$ \\
\hline HYPA & $92(28.6)$ & $1104.0 \pm 138$ & $86(26.7)$ & $1137.5 \pm 140.3$ & 0.94 & Reference \\
\hline LYQA & $54(16.8)$ & $1080.9 \pm 186.7$ & $65(20.2)$ & $1198.5 \pm 168.7$ & 0.55 & 0.29 \\
\hline LYPA & $59(18.3)$ & $782.5 \pm 185.9$ & $49(15.2)$ & $891.6 \pm 179.7$ & 0.86 & 0.63 \\
\hline LXPA & $31(9.6)$ & $916.2 \pm 267.1$ & $46(14.3)$ & $918.8 \pm 206.9$ & 0.57 & 0.09 \\
\hline LYPB & $39(12.1)$ & $410.1 \pm 181$ & $35(10.9)$ & $165.8 \pm 112.7$ & 0.33 & 0.88 \\
\hline LYQC & $35(10.9)$ & $330.1 \pm 159.8$ & $21(6.5)$ & $494.7 \pm 253.5$ & 0.25 & 0.16 \\
\hline HYPD & $9(2.8)$ & $413.7 \pm 380.3$ & $6(1.9)$ & $916.1 \pm 587.4$ & 0.16 & 0.54 \\
\hline HYPB & $3(0.9)$ & $146.1 \pm 286.4$ & $14(4.3)$ & $659.9 \pm 211.1$ & $\mathrm{P}=0.029$ & $P=0.013$ \\
\hline
\end{tabular}

$\mathrm{MBL}=$ mannose biding lectin. ${ }^{* a}$ Mann-Whitney test. ${ }^{\mathrm{b}}$ Chi-square test 
A total of 8 different haplotypes were found in our sample. The most frequent haplotypes in both groups were HYPA and LYQA with an average concentration greater than $1000 \mathrm{ng} / \mathrm{mL}$ (Table 3). Haplotype LYPA was present in $18.3 \%$ and $15.2 \%$ of the case and control samples, while LXPA was found in $9.6 \%$ and $14.3 \%$. Both showed levels of serum MBL between 700 and $1000 \mathrm{ng} / \mathrm{mL}$ (Table 3). The LYPB, LYQC, HYPD, HYPB haplotypes that showed average levels of serum MBL less than 700 had frequency lower than $13 \%$ in both analyzed groups (Table 3). The comparison between high producer haplotypes and MBL low producers has no significant association with the presence or absence of VL (Table 3).

\section{Association of MBL levels and MBL2 diplotypes}

The individuals were grouped by diplotypes according to their average concentration levels of MBL as shown in Table 4. The individuals with YA/YA and YA/XA diplotypes had an average concentration of MBL greater than or equal to 2000 $\mathrm{ng} / \mathrm{mL}$. The individuals with YA/YO and YA/XO diplotype had an average level of 1034.4 $\mathrm{ng} / \mathrm{mL}$, while the individuals with YO/YO diplotypes had a low or null level of MBL protein. The frequencies of this diplotypes were similar both in the case and control groups. None of these diplotypes were associated with VL (Table 4).

Table 4. Mannose-binding lectin (MBL) serum levels according to combined genotypes of the -221 promoter region and exon 1 of MBL2 in individuals. (a) Diplotypes with high levels; (b) Diplotypes with intermediate levels; (c) Diplotypes with null levels.

\begin{tabular}{|c|c|c|c|c|}
\hline Diplotypes & $\begin{array}{l}\text { Cases } \\
\mathrm{N}=161(\%)\end{array}$ & $\begin{array}{l}\text { Controls } \\
\mathrm{N}=161(\%)\end{array}$ & OR $(95 \% \mathrm{CI})$ & $\mathrm{P}$ value \\
\hline YA/YA; YA/XA ${ }^{\text {(a) }}$ & $88(55)$ & $94(58)$ & 1 & - \\
\hline $\mathrm{YA} / \mathrm{YO} ; \mathrm{XA} / \mathrm{XO}^{(\mathrm{b})}$ & $60(37)$ & $58(36)$ & $0.90[0.56-1.43]$ & 0.34 \\
\hline $\mathrm{YO} / \mathrm{YO}^{(\mathrm{c})}$ & $13(8)$ & $9(6)$ & $0.64[0.26-1.59]$ & 0.34 \\
\hline $\mathrm{YA} / \mathrm{YO} ; \mathrm{XA} / \mathrm{XO}+\mathrm{YO} / \mathrm{YO}^{(\mathrm{b}+\mathrm{c})}$ & $73(45)$ & $67(42)$ & $0.85[0.55-1.33]$ & 0.57 \\
\hline
\end{tabular}

\section{DISCUSSION}

The genetic background of the host has important impact in clinical manifestation of leishmaniasis. Variations in genes that are related to the immune system such as DLL1, TLR4, IL2RA and FCRN2 have been implicated in leishmaniasis development in human host (Mehrotra et al., 2012; Rasouli et al., 2012; Oliveira et al., 2015; Mishra et al., 2015b). The MBL protein is innate immune component that recognizes carbohydrate patterns, found on the surface of a large number of pathogenic microrganisms, leading to activation of the complement system by lectin pathway. The idea of using MBL2 polymorphisms as susceptibility / resistance markers for some diseases is very encouraging, since they could contribute, for example, to the adoption of prophylactic measures based on the MBL2 genotype of the individuals (Turner, 2003).

The role of MBL serum levels as well as MBL2 variants have been investigated in leishmaniasis in several regions around the world, but the results are contradictory. 
Previously, we reported that MBL levels in patients diagnosed with VL were similar to healthy individuals (Silva et al., 2015). In the present study, we demonstrated that genetic polymorphisms associated with low or high MBL production had also no influence on disease susceptibility caused by L. chagasi.

The allelic frequencies of exonic variants in the sample (case and control) showed that the $M B L 2 *$ A allele (wild) is the most common, followed by $M B L 2 * \mathrm{~B}, M B L 2 * \mathrm{C}$ and $M B L 2 * \mathrm{D}$ (Table 1). The defective variants had a frequency similar to the one found in studies performed on samples from populations neighbor to our sampling (Santos et al., 2001; Alonso et al., 2007). However, these alleles are unevenly distributed in relation to other populations. In African populations, $M B L 2 * \mathrm{~B}$ allele is non-existent or very rare, whereas among South American Amerindians (Argentina and Peru) it reaches very significant proportion, greater than $40 \%$ (Garred et al., 2006). In contrast, in the Amerindian populations from Argentina and Peru, the absence of $M B L 2 * \mathrm{C}$ allele is observed, which is the most frequent in different regions of Africa. In the region of Mozambique, $6 \%$ of the population is homozygous for this allele. Among Australian aborigines, the defective alleles are extremely rare or non-existent (Turner et al., 2000). In Brazil, the Guarani tribe, an indigenous population, has frequencies of $43 \%$ for $M B L * \mathrm{~B}$ allele and $0.4 \%$ for $M B L 2 * \mathrm{C}$ variant. $M B L 2 * \mathrm{D}$ allele was not found (Boldt \& Petzl-Erler, 2002).

The defective alleles MBL2*B, $\mathrm{C}$ and $\mathrm{D}$ (collectively identified as $\mathrm{O}$ allele) are kept in the population to confer selective advantage to the heterozygotes, compared to the functional homozygote (A/A) or defective (O/O) (Garred et al., 2006). Thus, the intermediate MBL levels observed in the heterozygous A/O may be the most appropriate phenotype for the innate protection against a wide variety of pathogens, since high levels observed in the homozygous A/A favor infections by certain intracellular parasites (Alonso et al., 2007; Messias-Reason et al., 2007; Cosar et al. 2008), whereas low levels in the homozygotes $\mathrm{O} / \mathrm{O}$ have been associated with reduce resistance to Plasmodium falciparum (Luty et al., 1998) and certain extracellular parasites (Antony et al., 2013).

Our results demonstrate that the presence of a defective allele $(M B L 2 * \mathrm{~B}, \mathrm{C}$ or $\mathrm{D})$ with functional heterozygous allele $(M B L 2 * \mathrm{~A})$ significantly reduces $(\mathrm{p}<0.0001) \mathrm{MBL}$ levels. In fact, the homozygotes for two defective alleles $(\mathrm{O} / \mathrm{O})$ showed undetectable levels of protein in both case and control groups (Figure 1). However, there was no significant difference between the frequency of genotypes (Table 1) or the average concentration of MBL protein on the three genotypes between the groups (Figure 1). These results indicate that MBL levels are influenced mainly by the genotype of the participants of this study and that the presence of the parasite does not influence the phenotype regarding to the production of MBL. Similarly, Asgharzadeh et al. (2007) in Iran, and Hamdi et al. (2013) in Morocco, also indicated no relationship between the functional genotype and VL occurrence. Santos et al. (2001) studying a Brazilian population, observed that individuals with a history of VL had higher levels of MBL than asymptomatic individuals, suggesting an influence of MBL protein level in clinical outcome of VL. This observation cannot be performed in our study, since we did not evaluate asymptomatic individuals, but only those with a positive history of the disease. However, it is important to note that Santos et al. (2001), also found no association between the exon 1 genotypes of MBL2 and infection with L. chagasi, which corroborates the results of the present study.

Because the variations in promoter region of MBL2 are also associated with different levels of MBL protein (Madsen et al., 1998) the present study also evaluated their 
association with LV. Regarding the three investigated polymorphisms in the promoter region $(-221 \mathrm{X} / \mathrm{Y} ;-551 \mathrm{H} / \mathrm{L}$ and $+4 \mathrm{P} / \mathrm{Q})$, no significant difference was observed between the frequencies of alleles in both groups. Previous studies had shown that these polymorphisms can influence the occurrence of VL disease, but the results are inconsistent. A recent study with Indian population found no relationship between $\mathrm{VL}$ and variants at promoter sites $-550 \mathrm{H} / \mathrm{L} ;-221 \mathrm{X} / \mathrm{Y}$, but the $+4 \mathrm{Q}$ allele, which leads to high levels of MBL, was associated with relative protection against VL (Mishra et al., 2015a). Individuals with -221YY genotype, which leads to high levels of MBL, had a higher risk of developing VL caused by $L$. infantum in Moroccan population (Hamdi et al., 2013). In contrast, the $-221 \mathrm{X}$ allele, that confers low levels of MBL, was associated to VL caused by L. guyanensis in Brazil (Araujo et al., 2015).

Although a large number of haplotypes resulting different combinations of alleles present in the coding region and promoter region of $M B L 2$ gene may occur, only seven haplotypes are commonly found: HYPA, LYPA, LYQA, LXPA, HYPD, LYPB and LYQC. Such fact is explained due to linkage disequilibrium of these genes (Pedroso et al., 2008). In our study, however, eight haplotypes were identified in $M B L 2$ gene (Table 3), being HYPA and LYQA the most frequent and HYPD and HYPB less frequent (Table 3).

The MBL2 haplotype can be classified as defective (LYPB, LYQC and HYPD) or functional (LXPA, LYQA, LYPA and HYPA) (Madsen et al, 1998). Among functional, HYPA and LYQA are associated with high levels of MBL in serum, whereas LYPA and LXPA are associated with intermediate to low levels. Our results support the classification suggested by Madsen et al. (1998) and a significant difference can be observed between MBL levels for each type of haplotype either in VL group or healthy group (Table 3). However, when comparing the groups, we found no differences in the distribution of frequencies and in MBL levels in seven of the eight haplotypes observed (Table 3). Only HYPB haplotype showed a significant difference both in frequency and MBL level between groups, being higher in the control group. It is possible that this difference is associated with another set of haplotype present in the genotype of control individuals, since the presence of at least one strong producer allele can significantly increase MBL levels. Also, additional single nucleotide polymorphisms within these common haplotypes can further explain the observed variation in functional MBL serum levels and should be considered in future association studies with a wider locus approach (Wiertsema et al., 2006).

A study with Iran population has shown that, there is no difference between the haplotypes in patients with VL compared with healthy individuals (Asgharzadeh et al., 2007). However, two recent studies have shown a higher frequency of HYPA haplotype among healthy individuals, indicating its possible protective role against the leishmaniasis (Mishra et al., 2015a; Araujo et al., 2015). The HYPA haplotype has also been already associated with the protection against Schistossoma haematobium (Antony et al., 2013). On the other hand, some studies have shown the inverse role of the high MBL expressor haplotypes. In infection caused by Mycobacterium leprae, the LYPA haplotype was associated with the occurrence of leprosy for both the lepromatous and the borderline forms (Messias-Reason et al., 2007).

Regarding the individuals grouped based on MBL levels, there was no difference between the groups on the frequency of diplotypes that induces high MBL levels (YA/YA +YA/XA) intermediate (YA/YO; XA/XO) and low/null (YO/YO). In contrast, Alonso and cols (2007) found a weak association between individuals with genotypes that induces high 
production of MBL (YA/YA +YA/XA) and VL occurrence, differing from Araujo et al. (2015), where diplotypes that results in high MBL levels were resistant to cutaneous leishmaniasis.

The data presented in this study corroborates the results previously demonstrated by our group, showing a lack of association of MBL levels and the occurrence of VL (Silva et al., 2015) caused by L. chagasi. Altogether, these results suggest that there is no influence of genotypes or serum MBL levels in the susceptibility to VL caused by $L$. chagasi in the studied population. These results differ from other studies in Brazil and other countries of Africa that report an association between polymorphism of the MBL 2 gene and leishmaniasis (Santos et al., 2001; Alonso et al., 2007; Asgharzadeh et al., 2007; Hamdi et al., 2013; Araujo et al., 2015; Mishra et al., 2015a). However, these associations are controversial, since genotypes conferring high production of MBL have already been associated with both susceptibility (Alonso et al., 2007; Asgharzadeh et al., 2007) and resistance (Araujo et al., 2015; Mishra et al., 2015a) to leishmaniasis. So, it is important to note that many variables can determine the course of a leishmaniasis infection. As we known, the mechanisms of immune response evasion are highly diversified among the species of Leishmania (Gupta et al., 2013; Freitas et al., 2016) and the immune response of the hosts are strongly influenced by the saliva composition of the insect vector (Gomes \& Oliveira, 2012). Therefore, it should be considered the variety of etiologic agent and insect vector as well as the ethnic social and the immunogenetic background of the host. These multifactorial characteristics could explain the conflicting results regarding the influence of MBL 2 polymorphisms on leishmaniasis in such different populations worldwide, indicating that the influence of genetic variations depends on the social context of population, the binomial parasite/vector, and the disease itself.

\section{ACKNOWLEDGMENTS}

The authors would like to thank the funding agencies Fundação de Amparo à Pesquisa e ao Desenvolvimento Científico e Tecnológico do Maranhão (FAPEMA), Fundação de Amparo à Pesquisa do Estado de São Paulo (FAPESP), Conselho Nacional de Desenvolvimento em Pesquisa (CNPq), and Coordenação de Aperfeiçoamento de Pessoal de Nível Superior (CAPES).

\section{REFERENCES}

Alonso D, Ferreira A, Ribolla P, Santos I, et al. (2007). Genotypes of the Mannan-Binding Lectin Gene and Susceptibility to Visceral Leishmaniasis and Clinical Complications. J. Infect. Dis. 195: 1212-1217.

Antony JS, Ojurongbe O, Van Tong H, Ouf EA, et al. (2013). Mannose-Binding Lectin and Susceptibility to Schistosomiasis. J. Infec. Dis. 207: 1675-1683.

Araujo FJ, Mesquita TG, Silva LD, Almeida SA, et al. (2015). Functional variations in MBL2 gene are associated with cutaneous leishmaniasis in the Amazonas state of Brazil. Genes Immun. 16: 284-288.

Asgharzadeh M, Mazloumi A, Kafil HS and Ghazanchae A (2007). Mannose-Binding Lectin Gene and Promoter Polymorphism in Visceral Leishmaniasis Caused by Leishmania infantum. Pak. J. Bio. Sci. 10: 1850-1854.

Badaro, R, Jones TC, Lorenco R, Cerf BJ, et al. (1986). A Prospective Study of Visceral Leishmaniasis in an Endemic Area of Brazil. J. Infec. Dis. 154: 639-649.

Boldt AB and Petzl-Erler ML (2002). A new strategy for mannose-binding lectin gene haplotyping. Hum. Mutat. 19: 296-306.

Cosar H, Ozkinay F, Onay H, Bayram N, et al. (2008). Low levels of mannose-binding lectin confers protection against tuberculosis in Turkish children. Eur. J. Clin. Microbiol. Infect. Dis. 27: 1165-1169. 
Fraser IP, Koziel H and Ezekowitz RB (1998). The serum mannose-binding protein and the macrophage mannose receptor are pattern recognition molecules that link innate and adaptive immunity. Semin. Immunol. 10: 363-372.

Freitas EO, Leoratti FMS, Freire-de-Lima CG, Morrot A, et al. (2016). The Contribution of Immune Evasive Mechanisms to Parasite Persistence in Visceral Leishmaniasis. Front. Immunol. 7: 1-7.

Garred P, Larsen F, Seyfarth J, Fujita R, et al. (2006). Mannose-binding lectin and its genetic variants. Genes Immun. 7: 85-94.

Gomes R and Oliveira F (2012). The Immune Response to Sand Fly Salivary Proteins and its Influence on Leishmania Immunity. Front. Immunol. 3: 110 (1-7).

Gupta G, Oghumu S and Satoskar AR (2013). Mechanisms of Immune Evasion in Leishmaniasis. Adv. Appl. Microbiol. 82: $155-184$.

Hamdi S, Ejghal R, Idrissi M, Ezzikouri S, et al. (2013). A variant in the promoter of MBL2 is associated with protection against visceral leishmaniasis in Morocco. Infect. Genet. Evol. 13: 162-167.

Kevric I, Cappel MA and Keeling JH (2015). New World and Old World Leishmania Infections. Dermatol. Clin. 33: 579-593.

Laison R and Rangel EF (2005). Lutzomyia longipalpis and the eco-epidemiology of American visceral leishmaniasis, with particular reference to Brazil: a review. Mem. Inst. Oswaldo Cruz. 100: 811-827.

Larsen F, Madsen HO, Sim RB, Koch C, et al. (2004). Disease-associated Mutations in Human Mannose-binding Lectin Compromise Oligomerization and Activity of the Final Protein. J. Biol. Chem. 279: 21302-21311.

Lipscombe RJ, Sumiya M, Hill AV, Lau YL, et al. (1992). High frequencies in African and non-African populations of independent mutations in the mannose binding protein gene. Hum. Mol. Genet. 1: 709-715.

Luty AJ, Kun JF and Kremsner PG (1998). Mannose-Binding Lectin Plasma Levels and Gene Polymorphisms in Plasmodium falciparum Malaria. J. Infect. Dis. 178: 1221-1224.

Madsen HO, Garred P, Kurtzhals JA, Lamm LU, et al. (1994). A new frequent allele is the missing link in the structural polymorphism of the human mannan-binding protein. Immunogenetics. 40: 37-44.

Madsen HO, Satz ML, Hogh, B, Svejgaard A, et al. (1998). Different molecular events result in low protein levels of mannan-binding lectin in populations from southeast Africa and South America. J. Immunol. 161: 3169-3175.

Mehrotra S, Fakiola M, Mishra A, Sudarshan M, et al. (2012). Genetic and functional evaluation of the role of DLL1 in susceptibility to visceral leishmaniasis in India. Infect. Genet. Evol. 12: 1195-1201.

Messias-Reason I, Boldt A, Braga AM, Stahlke EVRS, et al. (2007). The Association between Mannan-Binding Lectin Gene Polymorphism and Clinical Leprosy: New Insight into an Old Paradigm. J. Infect. Dis. 196: 1379-1385.

Mishra A, Antony JS, Gai P, Sundaravadivel P, et al. (2015a). Mannose-binding Lectin (MBL) as a susceptible host factor influencing Indian Visceral Leishmaniasis. Parasitol. Int. 64: 591-596.

Mishra A, Antony JS, Sundaravadivel P, Tong HV, et al. (2015b). Association of Ficolin-2 Serum Levels and FCN2 Genetic Variants with Indian Visceral Leishmaniasis. Plos One. 10 (5).

Oliveira PR, Dessein H, Romano A, Cabantous S, et al. (2015). IL2RAGenetic Variants Reduce IL-2-Dependent Responses and Aggravate Human Cutaneous Leishmaniasis. J. Immunol. 194: 2664-2672.

Pedroso MLA, Boldt AB, Pereira-Ferrari L, Steffensen R, et al. (2008). Mannan-binding lectin MBL2 gene polymorphism in chronic hepatitis $\mathrm{C}$ : association with the severity of liver fibrosis and response to interferon therapy. Clin. Exp. Immunol. 152: 258-264.

Queiroz MJ, Alves JG and Correia JB (2004). Leishmaniose visceral: características clínico-epidemiológicas em crianças de área endêmica. J. Pediatr. 80: 141-146.

Rasouli M, Keshavarz M, Kalani M, Moravej A, et al. (2012). Toll-like receptor 4 (TLR4) polymorphisms in Iranian patients with visceral leishmaniasis. Mol. Biol. Rep. 39: 10795-10802.

Sakthianandeswaren A, Foote SJ and Handman E (2009). The role of host genetics in leishmaniasis. Trends Parasitol. 25: 383-391.

Santos IKM, Costa CH, Krieger H, Feitosa MF, et al. (2001). Mannan-Binding Lectin Enhances Susceptibility to Visceral Leishmaniasis. Infec. Immun. 69: 5212-5215.

Sastry K, Herman GA, Day L, Deignan E, et al. (1989). The human mannose-binding protein gene. Exon structure reveals its evolutionary relationship to a human pulmonary surfactant gene and localization to chromosome $10 . J$. Exp. Med. 170: 1175-1189.

Silva E, Campos Júnior M, Monteiro S, Costa G, et al. (2015). Levels of mannose-binding lectin in individuals with visceral leishmaniasis in the northeast region of Brazil. Genet. Mol. Res. 14: 19094-19101.

Taylor ME, Brickell PM, Craig RK and Summerfield JA (1989). Structure and evolutionary origin of the gene encoding a human serum mannose-binding protein. Biochem. J. 262: 763-771.

Terai I, Kobayashi K, Matsushita M, Miyakawa H, et al. (2003). Relationship between gene polymorphisms of mannosebinding lectin (MBL) and two molecular forms of MBL. Eur. J. Immunol. 33: 2755-2763.

Turner MW, Dinan L, Heatley S, Jack, DL, et al. (2000). Restricted polymorphism of the mannose-binding lectin gene of indigenous Australians. Hum. Mol. Genet. 9: 1481-1486.

Turner MW (2003). The role of mannose-binding lectin in health and disease. Mol. Immunol. 40: 423-429.

Wiertsema SP, Herpers BL, Veenhoven RH, Salimans MM, et al. (2006). Functional polymorphisms in the mannanbinding lectin 2 gene: effect on MBL levels and otitis media. 117(6): 1344-50. 
Worthley DL, Bardy PG and Mullighan CG (2005). Mannose-binding lectin: biology and clinical implications. Intern. Med. J. 35: 548-555. 